\title{
Spatial variability and changes in carbon stocks of a Regosols (Psamments) cultivated with sisal
}

\author{
José A. A. S. do Sacramento ${ }^{1}$, Jorge A. G. Santos ${ }^{2}$, Diego C. Loureiro ${ }^{3}$, Oldair V. Costa ${ }^{2}$ \& Alide M. W. Cova \\ ${ }^{1}$ Universidade Federal do Oeste do Pará/Instituto de Biodiversidade e Florestas. Santarém, PA. E-mail: jassacramento@yahoo.com.br (Corresponding \\ author) - ORCID: 0000-0002-8839-2189 \\ ${ }^{2}$ Universidade Federal do Recôncavo da Bahia/Centro de Ciências Agrárias, Ambientai e Biológicas. Cruz das Almas, BA. E-mail: gonzaga.jorgeas@gmail.com \\ - ORCID: 0000-0001-7597-8706; oldairvinhas@gmail.com - ORCID: 0000-0003-4122-0563; alidewatanabe@yahoo.com.br - ORCID: 0000-0003-0570-7008 \\ ${ }^{3}$ Universidade Federal de Sergipe/Núcleo de Engenharia Agrícola. São Cristovão, SE. E-mail: campanaloureiro@gmail.com - ORCID: 0000-0003-0044-5280
}

\section{Key words:}

geostatistics

alternative farming

Caatinga

carbon emission factor

\begin{abstract}
A B S T R A C T
Information on spatial variability and soil carbon stocks after the conversion of Caatinga vegetation to different cropping systems is scarce. This study aimed to characterize the spatial variability and to evaluate the changes in carbon stocks and the emission of greenhouse gases after the conversion of Caatinga vegetation with different sisal cultivation systems. The study was carried out in three areas in the city of Valente, Bahia, two areas that had been cultivated for 20 years with sisal in either a traditional (TSC) or alternative (ASC) system, and the third area containing natural Caatinga vegetation. The cultivated soils were sampled at 40 soil sampling points with $15 \times 10 \mathrm{~m}$ spacing at depths of $0-0.20$ and 0.20 $0.40 \mathrm{~m}$. Total organic carbon (TOC) stocks had spatial dependence and the isoline maps allowed the variability in the studied depths to be analyzed. The conversion of Caatinga vegetation to sisal cultivation using traditional farming systems caused a $30 \%$ decrease in soil TOC stocks. Moreover, the alternative culture system caused an $11 \%$ increase in soil TOC stocks. The emission factor or carbon absorption due to changes in land use after 20 years was $0.66 \mathrm{t} \mathrm{ha}^{-1} \mathrm{yr}^{-1}$ of carbon in the traditional farming system and $-0.25 \mathrm{t} \mathrm{ha}^{-1} \mathrm{yr}^{-1}$ of carbon in the alternative culture system.
\end{abstract}

\section{Palavras-chave:} geoestatística cultivo alternativo caatinga fator de emissão de carbono

\section{Variabilidade espacial e mudanças nos estoques de carbono de um Neossolo Regolítico cultivado com sisal}

\section{R E S U M O}

As informações sobre variabilidade espacial e estoques de carbono no solo após a conversão da vegetação de caatinga para diferentes sistemas de cultivo são escassas. Este estudo objetivou caracterizar a variabilidade espacial e avaliar as mudanças nos estoques de $\mathrm{C}$ e a emissão de gases de efeito estufa após a conversão da vegetação de caatinga em diferentes sistemas de cultivo de sisal. O estudo foi realizado em três áreas, sendo duas áreas cultivadas por 20 anos com sisal em cultivo de sistema tradicional (CST) ou alternativo (CSA), e a terceira com vegetação natural de caatinga (CA), no município de Valente, BA. Os solos cultivados foram amostrados nos pontos de cruzamento de $10 \mathrm{x} 15$ $\mathrm{m}$, perfazendo 40 pontos por área, às profundidades de $0-0,20$ e 0,20-0,40 m. Os estoques de $C$ apresentaram dependência espacial e os mapas de isolinhas possibilitaram analisar a variabilidade nas profundidades estudadas. A conversão da vegetação de caatinga para o cultivo tradicional de sisal ocasionou uma redução de $30 \%$ nos estoques de C do solo. Porém, o sistema de cultivo alternativo ocasionou um incremento de $11 \%$ nos estoques de $\mathrm{C}$ do solo. $\mathrm{O}$ fator de emissão ou absorção de $\mathrm{C}$ devido à mudança de uso do solo após 20 anos foi de $0,66 \mathrm{t} \mathrm{ha}^{-1}$ ano $^{-1}$ de C para o sistema de cultivo tradicional e de $-0,25 \mathrm{t} \mathrm{ha}^{-1}$ ano $^{-1}$ de C para o sistema de cultivo alternativo. 


\section{INTRODUCTION}

Organic carbon storage in soil depends on the relationship between the contribution of organic waste to the soil and the decomposition process (Salcedo \& Sampaio, 2008). In Brazil, there is little information on the quantity and estimation of carbon stocks in soils under different uses and in different regions (Chaves \& Farias, 2008).

Inadequate soil management with plowing and sorting systems influences the emission of greenhouse gases and, consequently, soil organic carbon stock levels (Scala Júnior et al., 2006). However, the introduction of tree species into cropping systems has demonstrated greater efficiency in storing organic carbon in the soil in semi-arid regions (Abdalla et al., 2014; Dimassi et al., 2014). In Brazil, there are only a few studies that have studied this phenomenon (Maia et al., 2006; 2007; Sousa et al., 2012; Sacramento et al., 2013).

The production of sisal fiber (Agave sisalana) is one of the main income sources of small producers in semi-arid part of Bahia. The activity also generates organic waste that can be used as a source of carbon in the soil, providing better ecosystem functioning (Beates et al., 2013), and thus making agricultural soils more absorptive than greenhouse gas emitters.

Storing organic carbon in the soil is thus a major concern for research regarding the carbon cycle. Understanding the spatial variability of this nutrient and the main influencing factors is essential for evaluating the function and process of soil carbon storage (Li \& Shao, 2014). Additionally, information on the dynamics of organic carbon in soils cultivated with sisal is scarce. Therefore, the objective of the present study was to characterize the spatial variability and to evaluate the changes in carbon stocks and the emission of greenhouse gases after the conversion of Caatinga vegetation by different systems of sisal cultivation.

\section{MATERIAL AND Methods}

The present study was conducted from August 2012 to December 2013 on a farm located in the municipality of Valente, Bahia, which is situated between the geographic coordinates $-11^{\circ} 24^{\prime \prime} 44^{\prime} \mathrm{S}, 39^{\circ} 27^{\prime \prime} 43^{\prime} \mathrm{W}$ and $358 \mathrm{~m}$ altitude. The climate of the area is semi-arid, with average annual rainfall between 500 and $800 \mathrm{~mm}$. November and December receive the highest rainfall, and the average annual temperature varies between 20.7 and $26.8^{\circ} \mathrm{C}$. The soil of the experimental area presents a sequence of horizons A-C1-C2 and $2 \mathrm{Cr}$, with more than $1.00 \mathrm{~m}$ depth, sandy texture in all horizons, $\mathrm{pH}$ ranging from 5.9 to 6.4 , calcium in the range of 2.4 to $3.3 \mathrm{cmol}_{\mathrm{c}} \mathrm{kg}^{-1}$, magnesium between 0.7 and $1.3 \mathrm{cmol} \mathrm{kg}^{-1}$, potassium between 0.09 and $0.25 \mathrm{cmol}_{\mathrm{c}} \mathrm{kg}^{-1}$, and organic carbon between 1.6 and $3.5 \mathrm{~g} \mathrm{~kg}^{-1}$. The soil is classified as Regosols (Psamments) Eutrophic inceptisol based on criteria proposed by EMBRAPA (2013).

For the treatments, three areas were selected: one area with Caatinga vegetation (CA), another area with sisal in the traditional system cultivation (TSC) with plowing practice and harrowing, and a third area cultivated with sisal using the alternative system cultivation (ASC). These areas were all located on the Algodões farm, municipality of Valente, Bahia (Figure 1).

The CA area used in the present study was 1 ha in size.

The TSC area was 1.3 ha in size. The area was plowed, barred, left fallow for 3 months, weeded, and cultivated with corn and beans for 1 year. After this process, a sisal culture was implanted. The area did not receive any type of mineral or organic fertilization.

The ASC area was 1.2 ha in size. During the implantation of the sisal crop, the Caatinga vegetation was thinned to a density of 150 trees in the area and the cultivation of sisal occurred between the lines of trees. The area did not receive any type of mineral or organic fertilization, other than that deposited by the native trees. In addition to sisal, the main species that predominate in the area are Chicona sp., Annona crassiflora, Mimosa tenuiflora, Amburana cearenses, and Syagrus coronata, commonly called quina araticum, jurema umburana, and licuri, respectively.

The boundaries of the study areas were determined by walking and using the global positioning system (GPS). The points were georeferenced in the UTM system, Datum WGS 84, with sub metric precision (GPS - Geodetic/Leica L1 and L2). The points were post-processed in Topcontools software with the assistance of the Brazilian Monitoring Network based in Salvador.

The TSC and ASC experimental areas were divided into 75 $\times 80 \mathrm{~m}\left(6.000 \mathrm{~m}^{2}\right)$ sample rails. In each grid, 40 soil sampling points were collected with $15 \times 10 \mathrm{~m}$ spacing at two depths (0-0.20 and $0.20-0.40 \mathrm{~m})$, totaling 80 samples per area (Figure

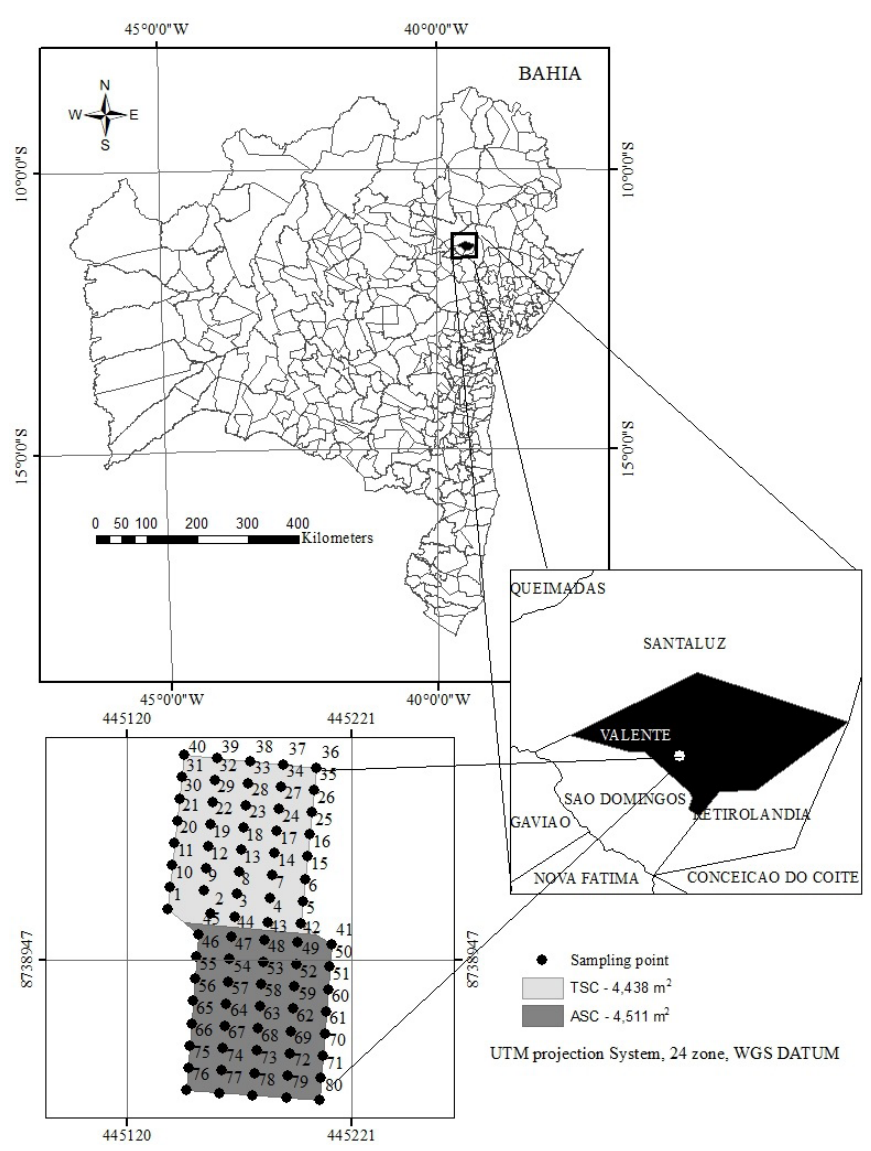

Figure 1. Location map and sample grid of areas cultivated with sisal at the Algodoes farm, Valente, Bahia 
1). In the CA area, because it was a homogeneous environment, five points were collected from each depth, totaling 170 samples over the three study areas. Soil samples were air dried and passed through sieves containing a $0.002 \mathrm{~m}$ diameter mesh.

The total organic carbon (TOC) content of the soil was determined by the oxidation of organic carbon with potassium dichromate in an acid medium, using an external heat source and subsequent titration with $0.2 \mathrm{~mol} \mathrm{~L}^{-1}$ ammoniacal ferrous sulfate (Yeomans \& Bremner, 1988).

Soil density was determined by the volumetric ring method, using the equation $\mathrm{Ds}=\mathrm{m} / \mathrm{v}$, where $\mathrm{m}$ is the soil mass $(\mathrm{g})$ at $105^{\circ} \mathrm{C}$ and $\mathrm{v}$ is the ring volume $\left(\mathrm{cm}^{-3}\right)$. The particle density was determined by the volumetric balloon method, based on data compiled by EMBRAPA (2011).

Soil carbon stocks were calculated based on the equation: $\mathrm{E}=\mathrm{d} \times \mathrm{h} \times(\mathrm{TOC}) / 10$, where, $\mathrm{E}$ is the stock of TOC $\left(\mathrm{t} \mathrm{ha}^{-1}\right)$; is the soil density $\left(\mathrm{kg} \mathrm{dm}^{-3}\right) ; \mathrm{h}$ is the thickness of the sampled layer $(\mathrm{cm})$; TOC is the total soil carbon content $\left(\mathrm{g} \mathrm{kg}^{-1}\right)$, and 10 is the unit converter.

After obtaining the carbon stocks, it was possible to determine the emission factor or soil carbon absorption (EFC) based on the method proposed in Volume 4 of the Guide to National Greenhouse Gas Inventories (Eggleston et al., 2006), which recommends the use of results obtained in the last 20 years to carry out national inventories, in accordance with the following Eq. 1:

$$
\mathrm{EFC}=\mathrm{h} \frac{[\mathrm{Cf}(\mathrm{h})-\mathrm{Ci}(\mathrm{h})]}{\mathrm{T}}
$$

where:

EFC - emission factor or uptake of soil carbon, $\mathrm{t} \mathrm{ha}^{-1} \mathrm{TOC}$ year $^{-1}$;

$\mathrm{h}$ - management system, which is equal to one;

$\mathrm{Cf}(\mathrm{h})$ - inventory of carbon in the final time in the last year of the inventory for the system $h$;

$\mathrm{Ci}(\mathrm{h})$ - initial carbon stock in the reference area; and,

$\mathrm{T}$ - time, year.

Analysis of the frequency distribution pattern of the data detected anomalous values, as well as organized and summarized the data, using the Sisvar computational statistical package (Ferreira, 2011). The Shapiro-Wilk normality test, distribution measure (asymmetry and kurtosis), location measurement (mean), and dispersion measures (standard deviation, variance, and coefficient of variation) were determined.

For comparison of averages between the treatments, the experimental design used randomized blocks. The treatments consisted of three areas. The soil TOC stock data underwent analysis of variance to verify the effect of the different cropping systems. The averages were compared using the Tukey test at $5 \%$ probability with the software Assistat Version 7.6 (Silva \& Azevedo, 2016).

Evaluation of spatial dependence was performed by the GEOESTAT software program (Vieira et al., 1983). This step comprised the calculation of experimental semivariograms, cross-validation (Jacknife) of fitted models, and ordinary kriging. The spatial variability maps of the soil TOC stocks were generated by ordinary kriging. The krigado file generated by GEOESTAT was exported to SURFER 7.02 (Golden Software Inc., 1999) for better representation and visualization of inventory variability maps. The degree of spatial dependence (GD) was calculated using Eq. 2 and was classified based on the procedure described by Zimback (2001) as follows: GD < $25 \%$ Weak; $25 \% \leq \mathrm{GD}<75 \%$ Moderate, and GD $\geq 75 \%$ Strong.

$$
\mathrm{DD}=\left[\frac{\mathrm{C}_{1}}{\left(\mathrm{C}_{0}+\mathrm{C}_{1}\right)}\right] \times 100
$$

where:

DD - degree of spatial dependence;

$\mathrm{C}_{0}$ - Pure Nugget Effect;

$\mathrm{C}_{1}$ - structural contribution; and,

$\mathrm{C}_{0}+\mathrm{C}_{1}$ - effect landing.

\section{Results AND Discussion}

TOC stocks decreased with increasing depth and the lowest values were observed in the TSC area. These differed significantly $(\mathrm{p}<0.05)$ from the CA and TSC areas and caused a decrease of approximately $30 \%$ in TOC stocks when compared to that in the CA area. In the ASC area, TOC stocks were higher than those in the CA area, with an increase of approximately $11 \%$ in soil TOC stocks (Table 1 ).

Table 1. Descriptive statistics of the Regosols (Psamments) Eutrophic inceptisol carbon stocks under natural Caatinga vegetation (CA) and sisal cultivated in the traditional system (TSC) and in the alternative system (ASC) at different depths

\begin{tabular}{|c|c|c|c|c|c|c|c|c|}
\hline Attribute & Areas & Average & DP & Kurtosis & CV (\%) & Variance & $\bar{D}$ & Asymmetry \\
\hline & & \multicolumn{7}{|c|}{$0-0.20 \mathrm{~m}$} \\
\hline \multirow{11}{*}{ TOC Stocks (t ha-1) } & TSC & $19.00 \mathrm{~b}$ & 4.35 & 1.92 & 22.89 & 18.93 & 0.94 & 1.06 \\
\hline & ASC & $29.30 \mathrm{a}$ & 9.00 & -0.34 & 30.73 & 81.10 & $0.97 \mathrm{~N}$ & 0.41 \\
\hline & $\mathrm{CA}$ & $26.92 \mathrm{a}$ & 10.17 & 0.49 & 37.79 & 103.54 & $0.94 \mathrm{~N}$ & 0.82 \\
\hline & & \multicolumn{7}{|c|}{$0.20-0.40 \mathrm{~m}$} \\
\hline & TSC & $8.72 \mathrm{c}$ & 2.77 & 0.61 & 31.77 & 7.69 & $0.97 \mathrm{~N}$ & 0.58 \\
\hline & ASC & $15.40 \mathrm{a}$ & 5.82 & 0.98 & 37.79 & 33.88 & $0.96 \mathrm{~N}$ & 0.60 \\
\hline & $\mathrm{CA}$ & $12.82 \mathrm{~b}$ & 4.82 & 3.61 & 37.61 & 23.24 & 0.76 & 1.89 \\
\hline & & \multicolumn{7}{|c|}{$0-0.40 \mathrm{~m}$} \\
\hline & TSC & $27.73 b$ & 5.68 & 0.97 & 20.49 & 32.30 & 0.93 & 1.00 \\
\hline & ASC & $44.70 \mathrm{a}$ & 13.01 & -0.62 & 29.11 & 169.39 & $0.96 \mathrm{~N}$ & 0.38 \\
\hline & $\mathrm{CA}$ & $39.74 \mathrm{a}$ & 14.45 & 2.4 & 36.37 & 208.97 & $0.89 \mathrm{~N}$ & 1.34 \\
\hline
\end{tabular}
in Valente, Bahia, Brazil

SD - Standard Deviation; CV - Coefficient of Variation; $d$ - Normal Distribution; N - Normal distribution for $p>0.05$ - Shapiro-Wilk test 
Soil carbon stocks are increased by the balance between carbon inputs and their subsequent decomposition (Robertson \& Nash, 2013; Liu et al., 2014). Liu et al. (2014) reported that in the semi-arid region the estimates of carbon storage in soil are relatively low and the incorporation of organic residues or the use of systems that favor the incorporation of these residues offer a practical way of increasing soil carbon stocks. These authors also reported that the increase in soil organic carbon stocks has other benefits for agriculture and the environment, such as increased soil fertility, increased aggregate stability, erosion control, and food production.

TOC emission factors calculated in the present study showed that there was an estimated loss (emission) of $0.66 \mathrm{t} \mathrm{ha}^{-1} \mathrm{yr}^{-1}$ of carbon in the TSC area and an estimated absorption of $-0.25 \mathrm{t} \mathrm{ha}^{-1}$ year $^{-1}$ of carbon in the ASC area, over the 20 -year period.

As there was no replacement of organic waste, mineral fertilizers, or inputs in the TSC area, it can be inferred that after the period of intense estimated loss of TOC, there was no recovery of TOC stocks in the soil in that area. In the ASC area, the replacement of TOC occurred and increased the carbon stock during those years.

Although the TSC area recorded a positive carbon emission factor, it can be considered low, compared to the result found by Fracetto et al. (2012) in areas of semi-arid regions cultivated with castor beans in Red Oxisols eutrophic clay texture. Those authors found values of $2.47 \mathrm{t} \mathrm{ha}^{-1}$ year $^{-1}$ of carbon, which is four times higher than the values found in the ASC area in the present study. This might be directly related to soil type and textural class. Sacramento et al. (2013) and Maia et al. (2007) who studied Luvisols clayey texture in agroforestry systems in the semi-arid region of Ceará found similar results to those found by Fracetto et al. (2012). The clay texture, in comparison to the sandy texture, can favor zones of accumulation and nonaccumulation via the redistribution of water in the soil surface.

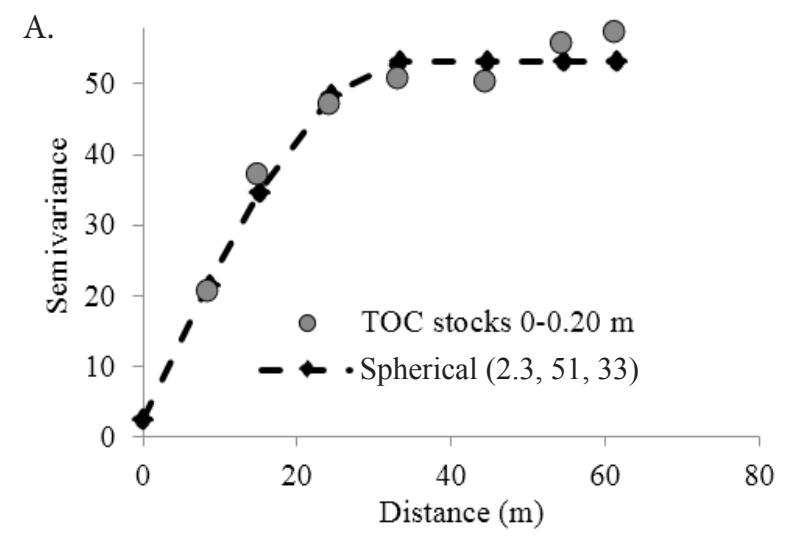

These conditions associated with microclimates can alter the soil response capacity by several factors, such as the potential of the soil to sequester carbon (Senthilkumar et al., 2009).

The TOC stocks, at depths of $0-0.20$ and $0-0.40 \mathrm{~m}$, fit the spherical (Figure 2A) and exponential (Figure 2B) models. At a depth of $0.20-0.40 \mathrm{~m}$, the TOC stocks showed a pure nugget effect (Table 2).

The largest range $(45 \mathrm{~m})$ was observed in TOC stocks at a depth of 0-0.40 m. The degree of spatial dependence was strong for the depths whose attributes presented adjustments to semivariogram models. TOC stocks at depth of $0-0.20 \mathrm{~m}$ presented the best fit $\left(\mathrm{R}^{2}=0.99\right)$, followed by TOC stocks at depth of $0-0.40 \mathrm{~m}\left(\mathrm{R}^{2}=0.83\right)$. Similar results of adjustments were found by Cruz et al. (2010) who analyzed physical attributes and organic carbon.

For TOC stocks, the distribution maps analyzed the spatial variability in depths of $0-0.20 \mathrm{~m}$ (Figure $3 \mathrm{~A}$ ) and $0-0.40 \mathrm{~m}$ (Figure 3B). The effect of the different cultivation systems can be clearly visualized, with the region containing the highest TOC values located in the lower part of the study area, precisely at the site representing the ASC area.

TOC stocks in the ASC area ranged from 28 to $50.5 \mathrm{t} \mathrm{ha}^{-1}$. Based on a study by Soto-Pinto et al. (2010), the potential of alternative systems, similar to that evaluated in the present study, to store carbon varies from 12 to $228 \mathrm{t} \mathrm{ha}^{-1}$, with a mean of $95 \mathrm{tha}^{-1}$ considering a depth of $1.00 \mathrm{~m}$. In the present study, considering the ASC area in the $0-0.40 \mathrm{~m}$ depth (Figure $3 \mathrm{~B}$ ), the values ranged from 42 to $72 \mathrm{t} \mathrm{ha}^{-1}$. It can be inferred, therefore, that if a depth of $1.00 \mathrm{~m}$ was considered, ASC would present higher values of TOC stocks and would be in agreement with the average established by Soto-Pinto et al. (2010). Thus, the hypothesis is reinforced that in the case of the substitution of native Caatinga vegetation, this should be done by alternative systems similar to the one evaluated in the present study.

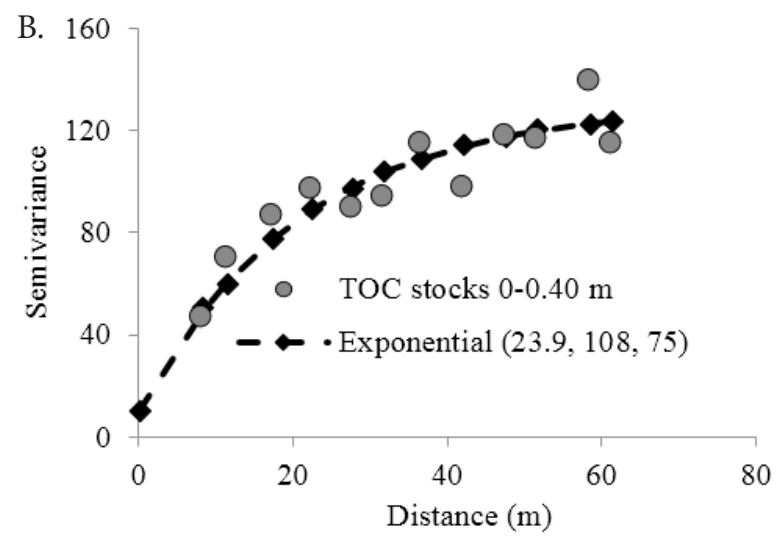

Figure 2. Semivariograms for total organic carbon stocks at depths of 0-0.20 m (A) and 0-0.40 m (B) in Regosols (Psamments) Eutrophic inceptisol, cultivated with sisal in Valente, BA

Table 2. Models of semivariograms of stocks of total organic carbon (TOC) of Regosols (Psamments) Eutrophic inceptisol in the areas of sisal study cultivated in the traditional system (TSC) and sisal cultivated in the alternative system (ASC)

\begin{tabular}{ccccccccc}
\hline Variable & Depth $(\mathbf{m})$ & Model & $\mathbf{C}_{0}$ & $\mathbf{C}_{1}$ & $\mathbf{a}$ & $\mathbf{r}^{2}$ & $\mathbf{G D}$ & Class \\
TOC socks & $0-0.20$ & Spherical & 2.3 & 51 & 33 & 0.99 & 95 & Strong \\
& $0.20-0.40$ & Pure Nugget Effect & & & & & & \\
TOC stocks & $0-0.40$ & Exponential & 0 & 120 & 45 & 0.83 & 100 & Strong \\
\hline
\end{tabular}

$\mathrm{C}_{0}$ - Pure nugget effect; $\mathrm{C}_{1}$ - Porch; a - Reach; GD - Degree of spatial dependence 

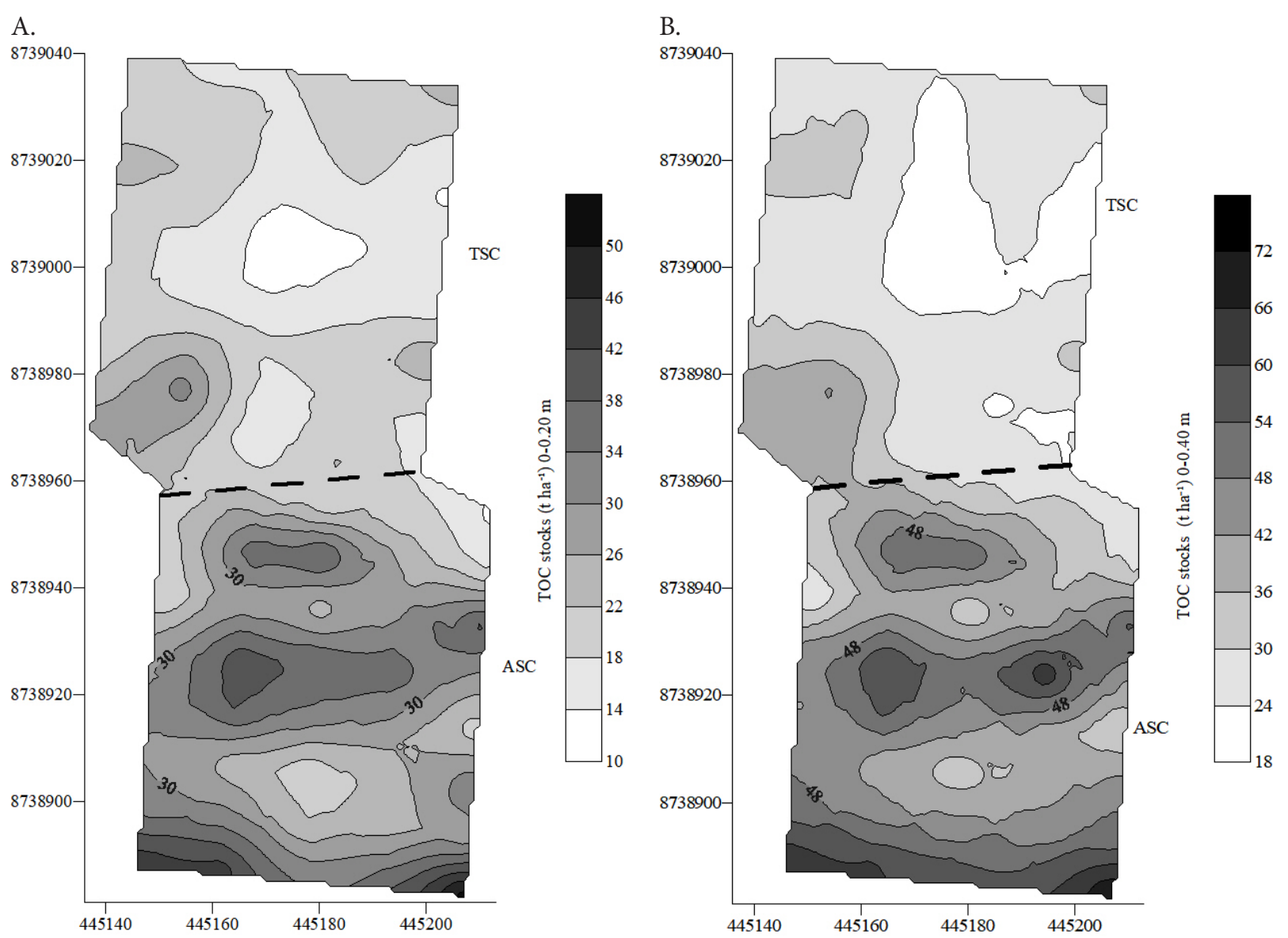

Figure 3. Spatial distribution for total organic carbon (TOC) stocks in the soil at depths of 0-0.20 m (A) and 0-0.40 m (B), with sisal grown in the traditional system (TSC) and alternative system (ASC)

\section{Conclusions}

1. Total organic carbon (TOC) stocks showed spatial dependence and the isoline maps could evaluate the variability at depths of $0-0.20$ and $0-0.40 \mathrm{~m}$.

2. The conversion of native Caatinga vegetation to sisal cultivation using the traditional cultivation system decreased the soil TOC stock by $30 \%$. The alternative cropping system increased soil TOC stocks by $11 \%$.

3. The carbon emission or absorption factor, owing to the change in land use after 20 years, was $0.66 \mathrm{tha}^{-1}$ year ${ }^{-1}$ of carbon for the traditional cultivation system and $-0.25 \mathrm{tha}^{-1}$ year-1 of carbon for the alternative cropping system.

\section{Literature Cited}

Abdalla, M.; Hastings, A.; Helmy, M.; Prescher, A.; Oborne, B.; Lanigan, G.; Forristal, D.; Killi, D.; Maratha, P.; Williams, M.; Rueangritsarakul, K.; Smith, P.; Nolan, P.; Jones, M. B. Assessing the combined use of reduced tillage and cover crops for mitigating greenhouse gas emissions from arable ecosystem. Geoderma, v.223-225, p.9-20, 2014. https://doi.org/10.1016/j. geoderma.2014.01.030

Beates, S. de; Meersmans, J.; Vanacker, V.; Quine, T. A.; Oost, K. van. Spatial variability and change in soil organic carbon stocks in response to recovery following land abandonment and erosion in mountainous drylands. Soil Use Management, v.29, p.65-76, 2013. https://doi.org/10.1111/sum.12017
Chaves, L. H. G.; Farias, C. H. de A. Variabilidade espacial do estoque de carbono nos Tabuleiros Costeiros da Paraíba: Solo cultivado com cana-de-açúcar. Revista Brasileira de Ciências Agrárias, v.3, p.20-25, 2008. https://doi.org/10.5039/agraria.v3ila235

Cruz, J. S.; Assis Júnior, R. N. A. de; Matias, S. S. R.; Camacho-Tamayo, J. H.; Tavares R. de C. Análise espacial de atributos físicos e carbono orgânico em Argissolo Vermelho-Amarelo cultivado com cana-de-açúcar. Ciência Agrotecnologia, v.34, p.271-278, 2010. https://doi.org/10.1590/S1413-70542010000200001

Dimassi, B.; Mary, B.; Wylleman, R.; Labreuche, J.; Couture, D.; Piraux, F.; Cohan J. P. Long-term effect of contrasted tillage and crop management on soil carbon dynamics during 41 years. Agriculture Ecosystems Environment, v.188, p.134-146, 2014. https://doi.org/10.1016/j.agee.2014.02.014

Eggleston, S.; Buendia, L.; Miwa, K.; Ngara, T.; Tanabe, K. A. In.: Intergovernmental Panel on Climate Change. Guidelines for national greenhouse gas inventories: Agriculture, forestry and other land use. (eds.). Hayama: IGES, 2006. 196p.

EMBRAPA - Empresa Brasileira de Pesquisa Agropecuária. Manual de métodos de análise de solos. 2.ed. Rio de Janeiro: Embrapa Solos,, 2011. 230p.

EMBRAPA - Empresa Brasileira de Pesquisa Agropecuária. Sistema brasileiro de classificação de solos. 3.ed. Rio de Janeiro: Embrapa Solos, 2013. 353p.

Ferreira, D. F. Sisvar: A computer statistical analysis system. Ciência e Agrotecnologia, v.35, p.1039-1042, 2011. https://doi.org/10.1590/ S1413-70542011000600001 
Fracetto, F. J. C.; Fracetto, G. G. M.; Cerri, C. C.; Feigl, B. J.; Siqueira Neto, M. Estoques de carbono e nitrogênio no solo cultivado com mamona na Caatinga. Revista Brasileira Ciência do Solo, v.36, p.1545-1552, 2012. https://doi.org/10.1590/S010006832012000500019

Golden Software Inc. Surfer for Windows: Release 7.0, contouring and 3D surface mapping for scientist's engineers User's Guide. New York: Golden Software Inc., 1999. 619p.

Li, D.; Shao, M. Soil organic carbon and influencing factors in different landscapes in an arid region of Northwestern China. Catena, v.116, p.95-104, 2014. https://doi.org/10.1016/j.catena.2013.12.014

Liu, D. L.; Anwar, M. R.; O’Leary, G.; Conyers, M. K. Managing wheat stubble as an effective approach to sequester soil carbon in a semi-arid environment: Spatial modelling. Geoderma, v.214-215, p.50-61, 2014. https://doi.org/10.1016/j.geoderma.2013.10.003

Maia, S. M. F.; Xavier, F. A. S.; Oliveira, T. S.; Mendonça, E. S.; Araújo Filho, J. A. Organic carbon pools in a Luvisol under agroforestry and conventional farming systems in the semi-arid region of Ceará, Brazil. Agroforesty Systems, v.71, p.127-138, 2007. https:// doi.org/10.1007/s10457-007-9063-8

Maia, S. M. F.; Xavier, F. A. da S, Oliveira, T. S. de; Mendonça, E. de S.; Araújo Filho, J. A. de. Impactos de sistemas agroflorestais e convencional sobre a qualidade do solo no semi-árido cearense. Revista Árvore, v.30, p.837-848, 2006. https://doi.org/10.1590/ S0100-67622006000500018

Robertson, F.; Nash, D. Limited potential for soil carbon accumulation using current cropping practices in Victoria, Australia. Agriculture Ecosystems Environment, v.165, p.130-140, 2013. https://doi.org/10.1016/j.agee.2012.11.004

Sacramento, J. A. A. S. do; Araújo, A. C. de M.; Escobar, M. E. O.; Xavier, F. A. da S.; Cavalcante, A. C. R.; Oliveira, T. S. de Soil carbon and nitrogen stocks in traditional agricultural and agroforestry systems in the semiarid region of Brazil. Revista Brasileira de Ciência do Solo, v.37, p.784-795, 2013. https://doi. org/10.1590/S0100-06832013000300025
Salcedo, I. H.; Sampaio, V. S. B. Matéria orgânica do solo no Bioma Caatinga. In: Santos, G. de A.; Silva, L. S. da; Canellas, L. P.; Camargo, F. A. de O. Fundamentos da matéria orgânica do solo, ecossistemas tropicais e subtropicais. Porto Alegre: Metrópole, 2008. Cap.22, p.419-441.

Scala Júnior, N. la; Bolonhezi, J.; Pereira, G. T. Short-term soil $\mathrm{CO}_{2}$ emission after conventional and reduced tillage of a no-till sugar cane area in southern Brazil. Soil Tillage Research, v.91, p.244-248, 2006. https://doi.org/10.1016/j.still.2005.11.012

Senthilkumar, S.; Kravchenko, A. N.; Robertson, G. P. Topography influences management system effects on total soil carbon and nitrogen. Soil Science Society of American Journal, v.73, p.20592067, 2009. https://doi.org/10.2136/sssaj2008.0392

Silva, F. de A. S. e; Azevedo, C. A. V. de. The Assistat software version 7.7 and its use in the analysis of experimental data. African Journal of Agricultural Research, v.11, p.3733-3740, 2016. https://doi. org/10.5897/AJAR2016.11522

Soto-Pinto, L.; Anzueto, M.; Mendoza, J.; Ferrer, G. J.; Jong, B. Carbon sequestration through agroforestry in indigenous communities of Chiapas, México. Agroforesty Systems, v.78, p.39-51, 2010. https://doi.org/10.1007/s10457-009-9247-5

Sousa, F. P.; Ferreira, T. O.; Mendonça, E. S.; Romero, R. E.; Oliveira, J. G. B. Carbon and nitrogen in degraded Brazilian semi-arid soils undergoing desertification. Agriculture Ecosystems Environment, v.148, p.11-21, 2012. https://doi.org/10.1016/j.agee.2011.11.009

Vieira, S. R.; Hatfield, J. L.; Nielsen, D. R.; Biggar, J. W. Geostatistical theory and application to variability of some agronomical properties. Hilgardia, v.51, p.1-75, 1983. https://doi.org/10.3733/ hilg.v51n03p075

Yeomans, J. C.; Bremner, J. M. A rapid and precise method for routine determination of organic carbon in soil. Communications in Soil Science and Plant Analysis, v.19, p.1467-1476, 1988. https://doi. org/10.1080/00103628809368027

Zimback, C. R. L. Análise espacial de atributos químicos de solos para fins de mapeamento da fertilidade do solo. Botucatu: UNESP, 2001. 114p. Tese Doutorado 